\title{
Lower Starting Dose of Afatinib for the Treatment of Metastatic Lung Adenocarcinoma Harboring Exon 21 and Exon 19 Mutations
}

\section{Yi-Chieh Chen}

Kaohsiung Medical University

Ming-Ju Tsai

Kaohsiung Medical University

Mei-Hsuan Lee

Kaohsiung Medical University

Chia-Yu Kuo

Kaohsiung Medical University

Mei-Chiou Shen

Kaohsiung Medical University

Ying-Ming Tsai

Kaohsiung Medical University

Huang-Chi Chen

Kaohsiung Medical University

Jen-Yu Hung

Kaohsiung Medical University

Ming-Shyan Huang

Kaohsiung Medical University

Inn-Wen Chong

Kaohsiung Medical University

Chih-Jen Yang ( $\nabla$ chjeya@cc.kmu.edu.tw )

Kaohsiung Medical University https://orcid.org/0000-0002-3576-7936

\section{Research article}

Keywords: epidermal growth factor receptor tyrosine kinase inhibitor, afatinib, lower starting dose, adverse drug reaction

Posted Date: October 9th, 2020

DOI: https://doi.org/10.21203/rs.3.rs-88923/v1 
License: (c) (i) This work is licensed under a Creative Commons Attribution 4.0 International License. Read Full License 


\section{Abstract}

\section{Background}

Afatinib has shown favorable response rates (RRs) and longer progression free survival (PFS) in lung cancer patients harboring EGFR mutations compared with standard platinum-based chemotherapy. However, serious adverse drug reactions (ADRs) limit the clinical application of afatinib.

\section{Methods}

We designed a retrospective study, enrolled all patients with metastatic lung adenocarcinoma who were diagnosed and treated with 30 or $\mathbf{4 0 ~} \mathrm{mg}$ afatinib as their starting dose in three Kaohsiung Medical University-affiliated hospitals in Taiwan

Results

A total of 179 patients were enrolled in the study, of which 102 (57\%) and 77 (43\%) received $30 \mathrm{mg}$ and $40 \mathrm{mg}$ afatinib daily as their initial treatment, respectively. The patients initially using $30 \mathrm{mg}$ afatinib daily had a similar RR ( $74 \%$ vs. $82 \%, p=0.1661)$, median PFS ( 14.5 months vs. 14.80 months, log-rank $p=$ 0.465 ) and median OS (34 months vs 25.2 months, log-rank $p=0.5982)$ compared with those initially using $40 \mathrm{mg}$ afatinib daily. Patients with the lower starting dose had fewer ADRs compared with patients receiving $40 \mathrm{mg}$ as their starting dose. The overall incidence of moderate $(49 \%$ vs $77 \%, p=0.002)$ or severe ( $7 \%$ vs $24 \%, p<0.0001$ ) ADRs was significantly lower in patients receiving $30 \mathrm{mg}$ afatinib compared with those receiving $40 \mathrm{mg}$.

\section{Conclusion}

Patients receiving $30 \mathrm{mg}$ afatinib as their starting dose had non-inferior RRs, PFS, OS and significantly fewer serious ADRs compared with those patients who received standard $40 \mathrm{mg}$ afatinib as their starting dose.

\section{Highlights}

1. Serious adverse drug reactions (ADRs) limit the clinical application of afatinib because up to half of all patients receiving standard $40 \mathrm{mg}$ afatinib as the initial starting dose have to discontinue their treatment or reduce their dosage due to severe ADRs.

2. The patients initially using $30 \mathrm{mg}$ afatinib daily had a similar RR ( $74 \%$ vs. $82 \%, p=0.1661)$, median PFS (14.5 months vs. 14.80 months, log-rank $p=0.465)$ and median OS (34 months vs 25.2 months, log-rank $p=0.5982$ ) compared with those initially using $40 \mathrm{mg}$ afatinib daily.

3. Patients with the lower starting dose had fewer ADRs including diarrhea, stomatitis, dry skin, acne and/or rash and pruritis compared with patients receiving $40 \mathrm{mg}$ as their starting dose. The overall 
incidence of grade $3(7 \%$ vs $24 \%, p<0.0001)$ ADRs was significantly lower in patients receiving $30 \mathrm{mg}$ afatinib compared with those receiving $40 \mathrm{mg}$.

\section{Introduction}

Lung cancer is a leading cause of cancer related mortality worldwide, including in Taiwan. Most lung cancer patients are diagnosed at an advanced stage meaning salvage therapy is recommended [1]. Platinum-based chemotherapy is a standard therapy for advanced stage lung cancer but has only been proven to have modest clinical efficacy [2, 3]; the response rates (RRs) to $1^{\text {st }}$ line cytotoxic chemotherapy for advanced non-small cell lung cancer (NSCLC) are 30 to $40 \%$, and all patients eventually develop resistance with a median survival of only 8 to 10 months [3].

In addition, chemotherapy causes a number of severe adverse drug reactions, (ADRs) such as nausea, vomiting, hematological toxicity and some unexpected life-threatening complications [3, 4], which can cause poor quality of life. Therefore, many new treatment strategies have been developed to improve the clinical efficacy of chemotherapy and to lower its toxicity. Driver mutations are believed to be involved in cancer pathogenesis and small molecular drugs designed to target the signal transduction pathway can result in cell apoptosis or death; these are often accompanied by fewer ADRs than standard chemotherapy $[5,6]$.

Therefore, many new target therapies were developed which have been proven to have better clinical efficacy compared with standard platinum-based chemotherapy [5]. Several large-scale phase 3 clinical trials have shown that lung cancer patients harboring susceptible epidermal growth factor receptor (EGFR) mutations who received tyrosine kinase inhibitor (TKI) have better clinical efficacy compared with platinum-based chemotherapy as determined by overall RRs, progression free survival (PFS) and quality of life [7-11]. Afatinib is an irreversible, second-generation EGFR TKI [12] which has been shown to have better RR, PFS and overall survival (OS) when administered to lung cancer patients who harbor susceptible EGFR mutations, compared with platinum-based chemotherapy $[13,14]$. Furthermore, afatinib has been shown to have a significantly longer PFS and time-to-treatment failure compared with gefitinib when used as the initial EGFR TKI in a head-to-head phase 3 clinical trial; ADRs were reported in $11 \%$ of patients taking $40 \mathrm{mg}$ afatinib daily and $4 \%$ of patients taking gefitinib [15]. A meta-analysis showed that in patients who received first- and second-generation EGFR TKIs, 40\% experienced grade 3-4 ADRs, while the risk of grade 3-4 ADRs was lower for gefitinib (29.1\%) than for erlotinib $(54.1 \%)$ or afatinib $(42.1 \%)$ [6] . Another pooled safety study concluded that grade 3-4 rash and diarrhea occurred significantly more frequently with afatinib therapy compared with erlotinib or gefitinib therapy [16]. Afatinib has been proven to have significantly longer OS in patients with exon 19 deletions [17]. Therefore, afatinib is a promising EGFR TKI for the management of patients with lung cancer with EGFR mutations.

However, patients receiving afatinib treatment always have more ADRs compared with $1^{\text {st }}$ generation EGFR TKIs in patients with EGFR mutations, and 28 to $53.3 \%$ of patients receiving standard $40 \mathrm{mg}$ afatinib daily had to discontinue or reduce their dose due to severe ADRs in the phase 3 Lux-Lung 3 and 
Lux-Lung 6 trials $[13,14,18]$. Real world data of $1^{\text {st }}$ line afatinib treatment showed that dose reduction occurred in 47.5 to $76.3 \%$ of cases $[19,20]$. Dose reductions were mainly due to ADRs and were more common in females, East Asian individuals and those with a low body-weight [21]. Therefore, methods for ameliorating ADRs whilst maintaining clinical efficacy are urgently needed for lung cancer patients receiving afatinib as their first line therapy. A lower starting dose of afatinib was tested by clinicians in clinical practice and several trials [22]. In May 2014, the Taiwan Nation Health Insurance Bureau permitted both $30 \mathrm{mg}$ and $40 \mathrm{mg}$ afatinib daily as a first line therapy for advanced lung adenocarcinoma with activating EGFR mutations.

Our preliminary report, a very small-scale study that only enrolled 48 patients with different starting doses, showed that patients who received $30 \mathrm{mg}$ afatinib as the starting dose had non-inferior PFS with fewer severe ADRs [23]. We believe that fewer adverse events, especially fewer severe ADRs will result in good drug compliance and a better quality of life during lung cancer treatment [24].

Here, we designed a retrospective trial which evaluated lower starting doses of afatinib in Taiwan. We investigated whether lung adenocarcinoma patients who harbored susceptible EGFR mutations and received lower starting doses had similar clinical efficacy and fewer severe ADRs compared with patients who received a higher starting dose of afatinib in a large-scale study.

\section{Patients And Methods}

\section{Patient identification}

Patients with metastatic lung adenocarcinoma who were diagnosed and treated between May $1^{\text {st }} 2014$ and July $31^{\text {st }} 2019$ in Kaohsiung Medical University Hospital (KMUH), Kaohsiung Municipal Ta-Tung Hospital and Kaohsiung Municipal Siaogang Hospital (all Kaohsiung Medical University-affiliated hospitals) in Taiwan, were identified and followed until Dec $31^{\text {st }}$ 2019. The diagnosis of lung adenocarcinoma was confirmed pathologically according to the World Health Organization pathology classification. Tumor staging was assessed according to the seventh American Joint Committee cancer staging system and confirmed by a lung cancer team. All adenocarcinoma specimens were analyzed using an EGFR RGQ kit (Qiagen, UK). The protocol was developed and validated by the Division of Molecular Diagnostics, Department of Laboratory Medicine, $\mathrm{KMUH}$, and utilized amplification refractory mutation specific (ARMS) polymerase chain reactions (PCRs) and Scorpion technologies for detection; direct sequencing was performed if a negative result was found in the ARMS PCR. The examination techniques were consistent with our previous studies [23, 25-28].

In the current study, we enrolled all individuals with exon 19 deletions and exon 21 L858R point mutations; they were all treatment-naïve and were treated with either 30 or $40 \mathrm{mg}$ afatinib daily as their first-line treatment for stage IV metastatic lung adenocarcinoma. Baseline clinical characteristics were determined by retrospective chart review, including age at diagnosis, gender, body weight, height, Eastern Cooperative Oncology Group (ECOG) performance status, glomerular filtration rate, smoking history, 
hepatitis $B$, hepatitis $C$, tuberculosis history, family history, thyroid transcription factor-1 (TTF-1), programmed death-ligand 1 (PDL-1), EGFR mutation, TNM status and number of metastatic sites on initial diagnosis.

The initial treatment response was classified based on serial imaging studies using the revised Response Evaluation Criteria in Solid Tumors (RECIST 1.1) criteria. The PFS and OS of the first-line treatment were defined as the time from the start of the first treatment to the date of disease progression on an imaging examination, and the date of death, respectively. ADRs were recorded by physicians and graded according to the Common Terminology Criteria for Adverse Events version 4.0.

\section{Statistical analysis}

Categorical variables and continuous variables were compared using the $\chi^{2}$ test and Student's t-test, respectively. Survival times were estimated using the Kaplan-Meier method, with differences between the two groups compared using the log-rank test. Using a backward variable selection method, keeping only variables with $p$ values $<0.1$, we developed reduced multivariable models with Cox regression analyses to determine predictive factors for PFS and OS. Hazard ratios (HR) with 95\% confidence intervals (Cls) are given for the predictive factors. All statistical analyses were performed using SAS software (version 9.4 for Windows, SAS Institute Inc., Cary, NC, USA). Statistical significance was set at a two-sided $p$ value of $<0.05$.

\section{Results}

During the study period, a total of 179 patients with stage IV lung adenocarcinoma harboring exon 19 deletions or an exon 21 L858R point mutation who received afatinib as their first-line therapy were enrolled (Table 1). Of these patients, 102 (57\%) received $30 \mathrm{mg}$ afatinib daily and 77 (43\%) received 40 mg daily as their initial treatment. Compared with those receiving $40 \mathrm{mg}$ afatinib daily, patients receiving $30 \mathrm{mg}$ daily as their initial dose were significantly older (65.7 $\pm 9.3 \mathrm{vs}$. $62.4 \pm 9.3$ years, $p=0.0199)$, had a significantly lower weight (58.2 \pm 12.5 vs. $62.4 \pm 9.9 \mathrm{~kg}, p=0.014)$ and a significantly lower BMI (1.6 \pm 0.2 vs. $\left.1.6 \pm 0.2 \mathrm{~m}^{2} p=0.0078\right)$, and were more likely to be female (72\% vs. $\left.48 \%\right)$. The number of metastatic sites at the initial diagnosis of lung cancer was significantly lower in patients receiving 30 mg afatinib $(p=0.0394)$ compared with those receiving $40 \mathrm{mg}$. In addition, significantly more patients with brain metastasis received $40 \mathrm{mg}$ afatinib as the initial dose as opposed to $30 \mathrm{mg}(42 \% \mathrm{vs} .21 \%, p=0.0023)$, but there was no significant difference for the other metastatic sites. There were no differences in body height, smoking history, glomerular filtration rate, serum albumin level, hepatitis $B$, tuberculosis history, family history, performance status, TTF-1, PDL-1 staining, and the EGFR gene mutation site (exon 19 or 21) of the cancer specimens between the two groups.

\section{Outcomes for $30 \mathrm{mg}$ and $40 \mathrm{mg}$ afatinib daily as the first-line treatment}

Patients initially receiving $30 \mathrm{mg}$ afatinib daily had similar response rates (74\% vs. 82\%; $p=0.1661)$ and similar disease control rates (99\% vs. 96\%) compared with those initially receiving 40 mg afatinib daily 
(Table 2). The PFS was not significantly different between patients receiving $30 \mathrm{mg}$ and $40 \mathrm{mg}$ afatinib daily (median PFS 14.5 months vs. 14.8 months, log-rank $p=0.465$; Figure 1 ). In terms of OS, there was no significant difference between the two patient groups (median OS 34.0 months vs. 25.2 months, logrank $p=0.5982$; Figure1B). Notable, only 13 patients (13\%) receiving $30 \mathrm{mg}$ afatinib and 5 patients $(6 \%)$ receiving $40 \mathrm{mg}$ afatinib daily received osimertinib after developing acquired resistance to afatinib. All other patients elected to have platinum-based chemotherapy or hospice care as their $2^{\text {nd }}$ line management.

To identify factors that can predict treatment outcomes, we built the multivariable Cox regression model in Table 3. In the univariable analysis, the independent predictive factors for PFS were number of metastatic sites $(\mathrm{HR}[95 \% \mathrm{Cl}]=1.28[1.09-1.51], p=0.0026)$ and dose reduction $(\mathrm{HR}[95 \% \mathrm{Cl}]=0.55[0.33-$ 0.91], $p=0.0209$ ). In the multivariable analysis, the independent predicting factors for PFS were number of metastatic sites $(\mathrm{HR}[95 \% \mathrm{Cl}]=1.28[1.09-1.50], p=0.0030)$ and dose reduction $(\mathrm{HR}[95 \% \mathrm{Cl}]=$ $0.56[0.34-0.92], p=0.02209)$.

In Table 4, we show how Cox regression analysis was used to identify factors associated with OS. In the univariable analysis, male $(\mathrm{HR}[95 \% \mathrm{Cl}]=1.65[1.03-2.63], p=0.0354), \mathrm{ECOG}$ status $(\mathrm{HR}[95 \% \mathrm{Cl}]=$ $2.50[1.50-4.19], p=0.0026)$ and number of metastatic sites (HR [95\% Cl] $=1.37$ [1.12-1.68], $p=0.0019)$ were significantly associated with OS. Further multivariable analysis indicated that those three factors were still significant independent risk factors for OS (male: (HR [95\% Cl] $=1.68$ [1.03-2.63], $p=0.0354)$; ECOG: $(\mathrm{HR}[95 \% \mathrm{Cl}]=2.21[1.31-3.74], p=0.0029)$; and number of metastatic sites: $(\mathrm{HR}[95 \% \mathrm{Cl}]=$ 1.34[1.09-1.65], $p=0.0056)$.

\section{ADRs for patients using $30 \mathrm{mg}$ or $40 \mathrm{mg}$ afatinib daily as the first-line treatment}

The most common ADRs in patients taking afatinib included skin rash and/or acne (81\%), diarrhea (74\%), dry skin (61\%) and paronychia (51\%) (Table 6). Patients receiving $30 \mathrm{mg}$ afatinib daily had a lower incidence of diarrhea ( $68 \%$ vs $82 \%$ ), acne and rash ( $78 \%$ vs $84 \%$ ), dry skin $(60 \%$ vs $64 \%$ ) and pruritis ( $23 \%$ vs $43 \%$ ) compared with those receiving $40 \mathrm{mg}$ afatinib daily (Table 5). Furthermore, patients receiving 30 mg daily had a significantly lower incidence of moderate (Grade 2 or higher) and severe (Grade 3 or higher) ADRs, including diarrhea, stomatitis, dry skin, acne and rash, and pruritis compared with patients receiving $40 \mathrm{mg}$ afatinib as the starting dose. The overall incidence of moderate ( $49 \mathrm{vs} .77 \%, p=0.002)$ or severe (7 vs. $24 \%, p<0.0001$ ) ADRs was significantly lower in patients receiving $30 \mathrm{mg}$ afatinib daily compared with those receiving $40 \mathrm{mg}$. In addition, no significant differences in drug induced hepatitis and interstitial lung disease were observed between the $30 \mathrm{mg}$ and $40 \mathrm{mg}$ groups in the present retrospective study.

Finally, 31 patients (40\%) who initially received $40 \mathrm{mg}$ afatinib daily had their dose reduced to $30 \mathrm{mg}$ daily due to $A D R s$, and 8 patients (8\%) who used $30 \mathrm{mg}$ afatinib daily had to discontinue or reduce their dose $(p<0.001), 2$ patients $(2 \%)$ with $30 \mathrm{mg}$ had and 2 patients $(3 \%)$ with $40 \mathrm{mg}$ had to discontinue afatinib completely (Supplemental table 1 ). 


\section{Cancer recurrence in patients using $30 \mathrm{mg}$ or $40 \mathrm{mg}$ afatinib daily as a first-line treatment}

Patients with $30 \mathrm{mg}$ had a higher incidence of bone metastasis as the recurrent site compared with the $40 \mathrm{mg}$ group ( $13 \%$ vs. $4 \%$ ). Notably, there was no significant difference in the occurrence of central nervous system (including brain or leptomeningeal) metastasis between patients in the $30 \mathrm{mg}$ and $40 \mathrm{mg}$ $(18 \%$ vs. $21 \%, p=0.5969)$ afatinib groups (Supplemental table 2$)$.

\section{Discussion}

To the best of our knowledge, this retrospective trial is the largest evaluation of patients receiving $30 \mathrm{mg}$ afatinib daily as the starting dose for treatment of metastatic lung adenocarcinoma harboring exon 21 L858R point mutations and exon 19 deletions. We demonstrated that patients who received $30 \mathrm{mg}$ afatinib as their starting dose had non-inferior RRs, PFS and OS compared with patients who received 40 mg afatinib as their starting dose, and they also had fewer severe ADRs.

Those patients receiving $30 \mathrm{mg}$ afatinib daily as the initial dose tended to be older, female, weigh less, have a lower BMI and have fewer metastatic sites on their initial diagnosis of lung cancer, compared with patients receiving $40 \mathrm{mg}$ afatinib. These results are similar to previous studies $[23,29]$

The patients initially using $30 \mathrm{mg}$ afatinib daily had similar RRs to the $40 \mathrm{mg}$ afatinib group, and the RR was comparable with previous studies (61-74\%). In two phase 3 clinical trials, Lux-Lung 3 and Lux-Lung 6 , the median PFS among patients who harbored EGFR mutations and took $40 \mathrm{mg}$ afatinib as their initial dose was 10.9 and 13.6 months, respectively. A real word practice study in Japan that enrolled 128 patients reported a median PFS of 17.8 months [20], while a phase 2 study which used a lower starting dose of $20 \mathrm{mg}$ afatinib that increased in 10-mg increments up to $50 \mathrm{mg} /$ day, reported a PFS of 15.2 months [19]. Another phase 2 study that enrolled 40 elderly patients had a shorter PFS of 12.9 months [22]. The current study revealed that the median PFS of patients who harbored exon 19 and exon 21 mutations and took afatinib 30 or $40 \mathrm{mg}$ afatinib as their starting dose was 14.5 and 14.8 months, respectively; no significant difference in PFS was observed between the two groups, the result is similar to our previous small-scaled study[23].

In terms of OS, the phase 3 Lux-Lung 3 and Lux-Lung 6 trials reported that the median OS was 31.4 and 33.3 months, respectively. Tanaka et a/ presented a real-world study of first line afatinib in Japan, with a reported median OS of 39.5 months [20]. In the Giotag trial, all patients initially received $40 \mathrm{mg}$ afatinib, followed by osimertinib if T790M acquired resistance was reported; the median OS was 41.3 months and the OS was as long as 45.7 months in patients with an exon 19 deletion [30]. In the present study, the OS was 34 and 25.2 months, respectively in the $30 \mathrm{mg}$ and $40 \mathrm{mg}$ groups which was not statistically significant. These results indicate that the clinical efficacy of $30 \mathrm{mg}$ afatinib as a starting dose was not inferior to $40 \mathrm{mg}$ afatinib as a starting dose in this multicenter retrospective study.

It should be noted that the current study enrolled patients from May 2014, however only 13 patients (13\%) in the $30 \mathrm{mg}$ group and 5 patients $(6 \%)$ in the $40 \mathrm{mg}$ group received osimertinib as a $2^{\text {nd }}$ line therapy. This 
is likely because osimertinib is very expensive and was not reimbursed by the Taiwanese National Health Insurance until April 2020. Therefore, the majority of patients with acquired-resistance to afatinib chose to receive platinum-based chemotherapy as their $2^{\text {nd }}$ line therapy as opposed to osimertinib.

In the current study, the independent predicting factors for PFS were 1) number of metastatic sites and 2) dose reduction due to severe ADRs. The independent predictive factors for OS were male gender, initial poor ECOG and number of metastatic sites. In Liang et al, patients with significant pretreatment weight loss (>10.0\% in 6 months) had a shorter median PFS, and patients with brain metastases had a poorer ECOG status and were associated with a shorter median PFS [31]. Tanaka et al also showed that patients with dose reduction had a significantly longer PFS than those without dose reduction in a real-world study (18.5 vs. 7.9 months, respectively; $p=0.018$ ) [20]. However, the average daily dose of $<20 \mathrm{mg}$ afatinib had a significantly shorter PFS compared with the other higher dose $(p=0.049)$ [32]. Another study of afatinib in Taiwan showed that OS was not affected by reductions in the afatinib dosage; they also indicated that brain metastases at diagnosis and treatment response to afatinib are two important prognostic factors for OS [33].

Previous clinical trials recommended that $40 \mathrm{mg}$ afatinib daily should be the starting dose in patients who harbor EGFR mutations, however, this dosage was often accompanied by serious ADRs and up to 28 to $53.3 \%$ of patients required dose reduction in the Lux-Lung 3 and Lux-Lung 6 studies $[14,18]$. In a realworld study in Japan, $48 \%$ of patients receiving standard $40 \mathrm{mg}$ afatinib had dose reduction and $23 \%$ of patients discontinued treatment due to ADRs [34].

In fact, many clinicians had experienced more severe ADRs in patients who received standard $40 \mathrm{mg}$ afatinib than those who received $1^{\text {st }}$ generation EGFR TKIs, such as gefitinib or erlotinib. There is an urgent need to find a reliable strategy for reducing ADRs associated with afatinib, whilst maintaining its clinical efficacy for the management of lung cancer. Therefore, in clinical practice many clinicians prescribe a lower starting dose of afatinib $[22,23]$ or perform dose modification $[19,21]$ to try and improve patient outcomes and adherence. In a non-interventional, observational study [21] of patients who started on $40 \mathrm{mg}$ afatinib daily, $67.1 \%$ underwent dose reduction, $86.5 \%$ of which occurred in the first 6 months. Dose reductions were more common in females, East Asian individuals, and those with a low body-weight [21]. In a post-marketing, observational study of afatinib in Japan [22], low-dose initial treatment was observed at a higher rate in females compared with males, and more often in patients with lower body weights compared with patients with higher body weights. A study by Imai et al enrolled 40 patients with a median age of 77 years (range, 70-85 years old) and all of them received $30 \mathrm{mg}$ afatinib as the starting dose; their RR and median PFS were similar to the present study and their ADRs were also acceptable [19].

Our study revealed that clinicians tended to prescribe $30 \mathrm{mg}$ afatinib to lung cancer patients with either a lower BSI, lower body weight or increased age. Recently, a prospective phase 2 clinical trial, which enrolled 46 patients assessed the efficacy and safety of low starting doses of afatinib followed by dose modification, according to its toxicity in patients with EGFR mutation-positive NSCLC. The study had a 
median PFS of 15.2 months (95\% Cl: $13.2-$ not estimable) and the 1-year OS rate was $95.6 \%(95 \% \mathrm{Cl}$ : $89.7 \%-100 \%)$ [22].

Since severe ADRs may discontinue the use of afatinib or lead to dose reduction, one must pay close attention to the incidence and severity of ADRs in the treatment of lung adenocarcinoma harboring exon 19 or exon 21 mutations. Of patients who received $40 \mathrm{mg}$ afatinib as their starting dose in the phase 3 Lux-Lung 3 and Lux-Lung 6 trials, 73.0 and $80.6 \%$, respectively experienced grade 3 or higher treatmentrelated ADRs; the incidence of ADRs dropped to 11.9 and $20.5 \%$, respectively after the dosage was lowered $[13,14,18]$. In a real-world study, grade 3 or higher ADRs occurred in $30.4 \%$ of patients [22]. The present study demonstrated that skin rash and/or acne, diarrhea, dry skin and paronychia were the most common ADRs and fewer events were observed in the $30 \mathrm{mg}$ group compared with the $40 \mathrm{mg}$ group, which is in keeping with the findings of our previous study [23]. Furthermore, patients who received $30 \mathrm{mg}$ afatinib daily had a significantly lower incidence of moderate to severe ADRs, including diarrhea, stomatitis, dry skin, acne and/or rash and pruritis; their overall incidence of moderate or severe ADRs was also significantly reduced. Fewer severe ADRs will lead to better drug compliance and a better overall quality of life for the patient. Besides, there was no increased incidence of recurrent central nervous system metastasis in patients receiving $30 \mathrm{mg}$ afatinib as the starting dose compared with those receiving $40 \mathrm{mg}$ in the current study.

Limitations First, although the study enrolled patients from three hospitals, the retrospective design of this study makes the results less reliable than standard prospective clinical trials. Second, the number of cases enrolled in the study was relatively low for a retrospective study. However, the number of patients enrolled receiving $30 \mathrm{mg}$ afatinib as the starting dose is the largest of any study to date. Third, patients with recurrent lung cancer were excluded from the current study. Fourth, we only enrolled lung adenocarcinoma patients and excluded those with squamous cell carcinoma or other rare types of lung cancer. Almost $99 \%$ of residents in Taiwan are covered by the Taiwan National Health Insurance bureau and only adenocarcinoma harboring susceptible EGFR mutations is reimbursed by the National Health Insurance bureau. Fifth, only $13 \%$ of patients in the $30 \mathrm{mg}$ group and $6 \%$ of patients in the $40 \mathrm{mg}$ group received osimertinib as their $2^{\text {nd }}$ line therapy. This is because osimertinib is expensive and was not reimbursed by the National Health Insurance in Taiwan until April 2020. Therefore, the majority of lung cancer patients with acquired-resistance to afatinib chose to receive platinum-based chemotherapy instead of osimertinib as a salvage therapy.

\section{Conclusion}

a lower starting dose of afatinib for patients with lung adenocarcinoma harboring susceptible EGFR mutations showed similar RR, PFS and OS compared with those receiving standard $40 \mathrm{mg}$ afatinib as the initial dose. The lower starting dose was accompanied by fewer common ADRs, and less moderate to severe ADRs. A further large-scale prospective trial is urgently needed to confirm these findings.

\section{Declarations}


Acknowledgements: The authors would like to thank all the hospital staff, the lung cancer teams and the patients in Kaohsiung Medical University Hospital, Kaohsiung Municipal Ta-Tung Hospital and Kaohsiung Municipal Siaokang Hospital in Taiwan.

Authors' contributions: The paper was conceived and designed by YC Chen, MJ Tsai and CJ Yang and contributed to by all the authors. JY Hung and MS Huang and IW Chong were as consultants and provided many valuable comments. MH Lee, CY Kuo, MC Shen and YM Tsai performed the interviews and conducted the qualitative content analysis. YC Chen, $\mathrm{HC}$ Chen, CJ Yang wrote the first draft of the manuscript, which was critically reviewed, revised, and approved for submission by all the authors.

Funding information: This work was supported by Kaohsiung Medical University Hospital.

Data availability: The datasets used and/or analyzed during the current study are available from the corresponding author on a reasonable request.

Compliance with ethical standards

Conflicts of Interest: The authors declare no conflict of interest.

Ethical approval: The Institutional Review Board of KMUH approved the current study (approval no. KMUHIRB-E(II)-20150162) and waived the need for written informed consent. In addition, patient records were anonymized and de-identified prior to all analyses.

\section{References}

1. Marino P, Pampallona S, Preatoni A, Cantoni A, Invernizzi F: Chemotherapy vs supportive care in advanced non-small-cell lung cancer. Results of a meta-analysis of the literature. Chest 1994, 106(3):861-865.

2. Scagliotti GV, Parikh P, von Pawel J, Biesma B, Vansteenkiste J, Manegold C, Serwatowski P, Gatzemeier U, Digumarti R, Zukin M et al: Phase III study comparing cisplatin plus gemcitabine with cisplatin plus pemetrexed in chemotherapy-naive patients with advanced-stage non-small-cell lung cancer. J Clin Oncol 2008, 26(21):3543-3551.

3. Schiller JH, Harrington D, Belani CP, Langer C, Sandler A, Krook J, Zhu J, Johnson DH, Eastern Cooperative Oncology G: Comparison of four chemotherapy regimens for advanced non-small-cell lung cancer. N Engl J Med 2002, 346(2):92-98.

4. Huang MS, Tsai JR, Shen MC, Chou SH, Yang CJ: Pemetrexed as a possible cause of severe rhabdomyolysis in the treatment of lung cancer. Lung Cancer 2012, 76(3):491-492.

5. Greenhalgh J, Dwan K, Boland A, Bates V, Vecchio F, Dundar Y, Jain P, Green JA: First-line treatment of advanced epidermal growth factor receptor (EGFR) mutation positive non-squamous non-small cell lung cancer. Cochrane Database Syst Rev 2016(5):CD010383. 
6. Ding PN, Lord SJ, Gebski V, Links M, Bray V, Gralla RJ, Yang JC, Lee CK: Risk of Treatment-Related Toxicities from EGFR Tyrosine Kinase Inhibitors: A Meta-analysis of Clinical Trials of Gefitinib, Erlotinib, and Afatinib in Advanced EGFR-Mutated Non-Small Cell Lung Cancer. J Thorac Onco/2017, 12(4):633-643.

7. Maemondo M, Inoue A, Kobayashi K, Sugawara S, Oizumi S, Isobe H, Gemma A, Harada M, Yoshizawa $\mathrm{H}$, Kinoshita I et al: Gefitinib or chemotherapy for non-small-cell lung cancer with mutated EGFR. N Engl J Med 2010, 362(25):2380-2388.

8. Mitsudomi T, Morita S, Yatabe Y, Negoro S, Okamoto I, Tsurutani J, Seto T, Satouchi M, Tada H, Hirashima $T$ et al: Gefitinib versus cisplatin plus docetaxel in patients with non-small-cell lung cancer harbouring mutations of the epidermal growth factor receptor (WJTOG3405): an open label, randomised phase 3 trial. Lancet Oncol 2010, 11(2):121-128.

9. Mok TS, Wu YL, Thongprasert S, Yang CH, Chu DT, Saijo N, Sunpaweravong P, Han B, Margono B, Ichinose $Y$ et al: Gefitinib or carboplatin-paclitaxel in pulmonary adenocarcinoma. $N$ Engl J Med 2009, 361(10):947-957.

10. Rosell R, Carcereny E, Gervais R, Vergnenegre A, Massuti B, Felip E, Palmero R, Garcia-Gomez R, Pallares $\mathrm{C}$, Sanchez $\mathrm{JM}$ et al: Erlotinib versus standard chemotherapy as first-line treatment for European patients with advanced EGFR mutation-positive non-small-cell lung cancer (EURTAC): a multicentre, open-label, randomised phase 3 trial. Lancet Oncol 2012, 13(3):239-246.

11. Zhou C, Wu YL, Chen G, Feng J, Liu XQ, Wang C, Zhang S, Wang J, Zhou S, Ren S et al: Erlotinib versus chemotherapy as first-line treatment for patients with advanced EGFR mutation-positive nonsmall-cell lung cancer (OPTIMAL, CTONG-0802): a multicentre, open-label, randomised, phase 3 study. Lancet Oncol2011, 12(8):735-742.

12. Solca F, Dahl G, Zoephel A, Bader G, Sanderson M, Klein C, Kraemer O, Himmelsbach F, Haaksma E, Adolf GR: Target binding properties and cellular activity of afatinib (BIBW 2992), an irreversible ErbB family blocker. J Pharmacol Exp Ther 2012, 343(2):342-350.

13. Sequist LV, Yang JC, Yamamoto N, O'Byrne K, Hirsh V, Mok T, Geater SL, Orlov S, Tsai CM, Boyer M et al: Phase III study of afatinib or cisplatin plus pemetrexed in patients with metastatic lung adenocarcinoma with EGFR mutations. J Clin Oncol 2013, 31(27):3327-3334.

14. Wu YL, Zhou C, Hu CP, Feng J, Lu S, Huang Y, Li W, Hou M, Shi JH, Lee KY et al: Afatinib versus cisplatin plus gemcitabine for first-line treatment of Asian patients with advanced non-small-cell lung cancer harbouring EGFR mutations (LUX-Lung 6): an open-label, randomised phase 3 trial. Lancet Oncol 2014, 15(2):213-222.

15. Park K, Tan EH, O'Byrne K, Zhang L, Boyer M, Mok T, Hirsh V, Yang JC, Lee KH, Lu S et al: Afatinib versus gefitinib as first-line treatment of patients with EGFR mutation-positive non-small-cell lung cancer (LUX-Lung 7): a phase 2B, open-label, randomised controlled trial. Lancet Oncol 2016, 17(5):577-589.

16. Takeda M, Okamoto I, Nakagawa K: Pooled safety analysis of EGFR-TKI treatment for EGFR mutation-positive non-small cell lung cancer. Lung Cancer 2015, 88(1):74-79. 
17. Yang JC, Wu YL, Schuler M, Sebastian M, Popat S, Yamamoto N, Zhou C, Hu CP, O'Byrne K, Feng J et al: Afatinib versus cisplatin-based chemotherapy for EGFR mutation-positive lung adenocarcinoma (LUX-Lung 3 and LUX-Lung 6): analysis of overall survival data from two randomised, phase 3 trials. Lancet Oncol 2015, 16(2):141-151.

18. Yang JC, Sequist LV, Zhou C, Schuler M, Geater SL, Mok T, Hu CP, Yamamoto N, Feng J, O'Byrne K et al: Effect of dose adjustment on the safety and efficacy of afatinib for EGFR mutation-positive lung adenocarcinoma: post hoc analyses of the randomized LUX-Lung 3 and 6 trials. Ann Oncol 2016, 27(11):2103-2110.

19. Imai H, Kaira K, Suzuki K, Anzai M, Tsuda T, Ishizuka T, Kuwako T, Naruse I, Nemoto K, Uchino J et al: A phase II study of afatinib treatment for elderly patients with previously untreated advanced nonsmall-cell lung cancer harboring EGFR mutations. Lung Cancer 2018, 126:41-47.

20. Tanaka H, Taima K, Itoga M, Ishioka Y, Baba K, Shiratori T, Sakamoto H, Tsuchiya J, Nakagawa H, Hasegawa $Y$ et al: Real-world study of afatinib in first-line or re-challenge settings for patients with EGFR mutant non-small cell lung cancer. Med Oncol 2019, 36(6):57.

21. Halmos B, Tan EH, Soo RA, Cadranel J, Lee MK, Foucher P, Hsia TC, Hochmair M, Griesinger F, Hida T et al: Impact of afatinib dose modification on safety and effectiveness in patients with EGFR mutation-positive advanced NSCLC: Results from a global real-world study (RealGiDo). Lung Cancer 2019, 127:103-111.

22. Yokoyama T, Yoshioka H, Fujimoto D, Demura Y, Hirano K, Kawai T, Kagami R, Washio Y, Ishida T, Kogo $\mathrm{M}$ et al: A phase II study of low starting dose of afatinib as first-line treatment in patients with EGFR mutation-positive non-small-cell lung cancer (KTORG1402). Lung Cancer 2019, 135:175-180.

23. Yang CJ, Tsai MJ, Hung JY, Lee MH, Tsai YM, Tsai YC, Hsu JF, Liu TC, Huang MS, Chong IW: The clinical efficacy of Afatinib $30 \mathrm{mg}$ daily as starting dose may not be inferior to Afatinib $40 \mathrm{mg}$ daily in patients with stage IV lung Adenocarcinoma harboring exon 19 or exon 21 mutations. BMC Pharmacol Toxicol 2017, 18(1):82.

24. Chang HL, Chen YH, Taiwan HC, Yang CJ: EGFR Tyrosine Kinase Inhibitor-Associated Interstitial Lung Disease During the Coronavirus Disease 2019 Pandemic. J Thorac Oncol 2020.

25. Tsai MJ, Hung JY, Lee MH, Kuo CY, Tsai YC, Tsai YM, Liu TC, Yang CJ, Huang MS, Chong IW: Better Progression-Free Survival in Elderly Patients with Stage IV Lung Adenocarcinoma Harboring Uncommon Epidermal Growth Factor Receptor Mutations Treated with the First-line Tyrosine Kinase Inhibitors. Cancers (Basel) 2018, 10(11).

26. Yang CJ, Hung JY, Tsai MJ, Wu KL, Liu TC, Chou SH, Lee JY, Hsu JS, Huang MS, Chong IW: The salvage therapy in lung adenocarcinoma initially harbored susceptible EGFR mutation and acquired resistance occurred to the first-line gefitinib and second-line cytotoxic chemotherapy. BMC Pharmacol Toxicol 2017, 18(1):21.

27. Yang CJ, Tsai MJ, Hung JY, Liu TC, Chou SH, Lee JY, Hsu JS, Tsai YM, Huang MS, Chong IW: Pemetrexed had significantly better clinical efficacy in patients with stage IV lung adenocarcinoma 
with susceptible EGFR mutations receiving platinum-based chemotherapy after developing resistance to the first-line gefitinib treatment. Onco Targets Ther 2016, 9:1579-1587.

28. Yang CJ, Tsai MJ, Hung JY, Tsai YM, Lee JY, Chou SH, Liu TC, Shen MC, Huang MS, Chong IW: Poorer prognosis in Taiwanese female ever smokers with stage IV lung adenocarcinoma who were readministered a tyrosine kinase inhibitor. Onco Targets Ther 2016, 9:1511-1518.

29. Liu CY, Wang CL, Li SH, Hsu PC, Chen CH, Lin TY, Kuo CH, Fang YF, Ko HW, Yu CT et al: The efficacy of $\mathbf{4 0} \mathrm{mg}$ versus dose deescalation to less than $\mathbf{4 0} \mathrm{mg}$ of afatinib (Giotrif) as the first-line therapy for patients with primary lung adenocarcinoma harboring favorable epidermal growth factor mutations. Oncotarget 2017, 8(57):97602-97612.

30. Hochmair MJ, Morabito A, Hao D, Yang CT, Soo RA, Yang JC, Gucalp R, Halmos B, Wang L, Marten A et al: Sequential afatinib and osimertinib in patients with EGFR mutation-positive non-small-cell lung cancer: updated analysis of the observational GioTag study. Future Oncol 2019, 15(25):2905-2914.

31. Liang SK, Hsieh MS, Lee MR, Keng LT, Ko JC, Shih JY: Real-world experience of afatinib as a first-line therapy for advanced EGFR mutation-positive lung adenocarcinoma. Oncotarget 2017, 8(52):9043090443.

32. Lim CK, Wei YF, Tsai MS, Chen KY, Shih JY, Yu CJ: Treatment effectiveness and tolerability of afatinib at different doses in patients with EGFR-mutated lung adenocarcinoma: How low can we go? Eur $J$ Cancer 2018, 103:32-40.

33. Liang SK, Lee MR, Liao WY, Ho CC, Ko JC, Shih JY: Prognostic factors of afatinib as a first-line therapy for advanced EGFR mutation-positive lung adenocarcinoma: a real-world, large cohort study. Oncotarget 2018, 9(34):23749-23760.

34. Tamura K, Nukiwa T, Gemma A, Yamamoto N, Mizushima M, Ochai K, Ikeda R, Azuma H, Nakanishi Y: Real-world treatment of over 1600 Japanese patients with EGFR mutation-positive non-small cell lung cancer with daily afatinib. Int J Clin Oncol2019, 24(8):917-926.

\section{Tables}

Table 1. Clinical characteristics and treatment responses for all patients 


\begin{tabular}{|c|c|c|c|c|}
\hline Variables & $\begin{array}{l}\text { All } \\
\text { patients }\end{array}$ & $\begin{array}{l}\text { Afatinib } 30 \mathrm{mg} \\
\text { QD }\end{array}$ & $\begin{array}{l}\text { Afatinib } 40 \mathrm{mg} \\
\text { QD }\end{array}$ & $\begin{array}{l}\mathrm{P} \\
\text { value }\end{array}$ \\
\hline$N(\%)$ & 179 & 102 & 77 & \\
\hline Age (year) -mean $\pm S D$ & $\begin{array}{l}64.3 \pm \\
9.4\end{array}$ & $65.7 \pm 9.3$ & $62.4 \pm 9.3$ & 0.0199 \\
\hline Age -n (\%) & & & & 0.0212 \\
\hline$<65$ years old & $80(45 \%)$ & $38(37 \%)$ & $42(55 \%)$ & \\
\hline$\geqq 65$ years old & $99(55 \%)$ & $64(63 \%)$ & $35(45 \%)$ & \\
\hline Sex -n (\%) & & & & 0.0014 \\
\hline Female & $\begin{array}{l}110 \\
(61 \%)\end{array}$ & $73(72 \%)$ & $37(48 \%)$ & \\
\hline Male & $69(39 \%)$ & $29(28 \%)$ & $40(52 \%)$ & \\
\hline Smoking history -n (\%) & & & & 0.9349 \\
\hline Never smoker & $\begin{array}{l}140 \\
(78 \%)\end{array}$ & $80(78 \%)$ & $60(78 \%)$ & \\
\hline Ever smoker & $39(22 \%)$ & $22(22 \%)$ & $17(22 \%)$ & \\
\hline Height $(\mathrm{cm})$-mean \pm SD & $160 \pm 8$ & $159.1 \pm 7.7$ & $161.2 \pm 8.4$ & 0.0905 \\
\hline Weight (kg)-mean \pm SD & $60 \pm 11.6$ & $58.2 \pm 12.5$ & $62.4 \pm 9.9$ & 0.014 \\
\hline Body mass index $\left(\mathrm{kg} / \mathrm{m}^{2}\right)$-mean $\pm \mathrm{SD}$ & $\begin{array}{l}23.3 \pm \\
3.6\end{array}$ & $22.8 \pm 3.7$ & $24 \pm 3.4$ & 0.0339 \\
\hline Body surface area $\left(\mathrm{m}^{2}\right)$-mean $\pm S D$ & $1.6 \pm 0.2$ & $1.6 \pm 0.2$ & $1.7 \pm 0.2$ & 0.0078 \\
\hline $\begin{array}{l}\text { Serum creatinine level }(\mathrm{mg} / \mathrm{dL}) \text {-mean } \\
\pm \mathrm{SD}\end{array}$ & $0.8 \pm 0.3$ & $0.8 \pm 0.3$ & $0.8 \pm 0.3$ & 0.4561 \\
\hline eCCr-CG $(\mathrm{mL} / \mathrm{min})-\mathrm{mean} \pm \mathrm{Sd}^{*}$ & $\begin{array}{l}77.1 \pm \\
26.8\end{array}$ & $73.7 \pm 25.9$ & $81.5 \pm 27.5$ & 0.0566 \\
\hline $\begin{array}{l}\text { eGFR-MDRD }\left(\mathrm{mL} / \mathrm{min} / 1.73 \mathrm{~m}^{2}\right) \text {-mean } \\
\pm \mathrm{Sd}^{\star \star}\end{array}$ & $88.8 \pm 27$ & $88 \pm 26.8$ & $89.8 \pm 27.4$ & 0.6628 \\
\hline Serum albumin (mg/dL) & $4 \pm 0.5$ & $4 \pm 0.4$ & $4.1 \pm 0.5$ & 0.2751 \\
\hline GOT (U/L) -mean \pm SD & $\begin{array}{l}29.6 \pm \\
22.8\end{array}$ & $31.4 \pm 28.7$ & $27.3 \pm 10.4$ & 0.1835 \\
\hline GPT (U/L) -mean \pm SD & $\begin{array}{l}26.5 \pm \\
25.1\end{array}$ & $26.7 \pm 28.5$ & $26.3 \pm 20$ & 0.9178 \\
\hline HBV $(\%)^{\star \star \star}$ & & & & 0.4999 \\
\hline Negative & 147 & $86(85 \%)$ & $61(81 \%)$ & \\
\hline
\end{tabular}




\begin{tabular}{|c|c|c|c|c|}
\hline Positive & $29(16 \%)$ & $15(15 \%)$ & 14 (19\%) & \\
\hline $\mathrm{HCV}(\%)^{\star \star \star}$ & & & & 0.037 \\
\hline Negative & $\begin{array}{l}165 \\
(94 \%)\end{array}$ & $98(97 \%)$ & 67 (89\%) & \\
\hline Positive & $11(6 \%)$ & $3(3 \%)$ & $8(11 \%)$ & \\
\hline Old TB (\%) & & & & 0.8901 \\
\hline Negative & $\begin{array}{l}174 \\
(97 \%)\end{array}$ & 99 (97\%) & 75 (97\%) & \\
\hline Positive & $5(3 \%)$ & $3(3 \%)$ & $2(3 \%)$ & \\
\hline Family history (\%) & & & & 0.0859 \\
\hline Negative & $\begin{array}{l}168 \\
(94 \%)\end{array}$ & $93(91 \%)$ & 75 (97\%) & \\
\hline Positive & $11(6 \%)$ & $9(9 \%)$ & $2(3 \%)$ & \\
\hline
\end{tabular}

Performance status while starting afatinib -n (\%)

0.1024

$\begin{array}{llll}\text { ECOG }<2 & \begin{array}{l}146 \\ (82 \%)\end{array} & 79(77 \%) & 67(87 \%) \\ \text { ECOG } \geqq 2 & 33(18 \%) & 23(23 \%) & 10(13 \%)\end{array}$

TTF-1 stating $-\mathrm{n}(\%)^{\star \star *}$

Positive

$\begin{array}{ll}170 & 99(100 \%)\end{array} \quad 71(100 \%)$

PDL-1 performance (\%) ${ }^{\star \star \star}$

\begin{tabular}{|c|c|c|c|c|}
\hline PDL-1 $\leqq 0$ & $33(38 \%)$ & $16(34 \%)$ & 17 (41\%) & \\
\hline PDL-1 >0 & $55(63 \%)$ & 31 (66\%) & $24(59 \%)$ & \\
\hline $\begin{array}{l}\text { Susceptible status of EGFR mutation } \\
\text { (\%) }\end{array}$ & $\begin{array}{l}179 \\
(100 \%)\end{array}$ & $102(100 \%)$ & 77 (100\%) & 0.9356 \\
\hline
\end{tabular}

EGFR gene mutation site $-n(\%)$

\begin{tabular}{|c|c|c|c|c|}
\hline Exon 19 & $95(53 \%)$ & 60 (59\%) & 35 (45\%) & 0.076 \\
\hline Exon 21 & $85(47 \%)$ & $42(41 \%)$ & 43 (56\%) & 0.0517 \\
\hline $\begin{array}{l}\text { Stage } 3 \mathrm{BC}+4 \text { positive of cancer stage } \\
(\%)\end{array}$ & $\begin{array}{l}179 \\
(100 \%)\end{array}$ & $102(100 \%)$ & 77 (100\%) & 0.4366 \\
\hline \multicolumn{5}{|l|}{ TNM staging (\%) } \\
\hline N2-3 & 112 & 67 (66\%) & 45 (58\%) & 0.3214 \\
\hline
\end{tabular}


M1a-c

Number of metastatic sites on initial diagnosis $-\mathrm{n}(\%)$

\begin{tabular}{|lllll|}
\hline 0 site & $6(3 \%)$ & $6(6 \%)$ & $0(0 \%)$ & \\
\hline 1 site & $61(34 \%)$ & $38(37 \%)$ & $23(30 \%)$ & \\
\hline 2 sites & 112 & $58(57 \%)$ & $54(70 \%)$ & \\
\hline Metastatic sites on initial diagnosis $-n(\%)$ & $(63 \%)$ & & & \\
\hline Brain metastasis & $53(30 \%)$ & $21(21 \%)$ & $32(42 \%)$ & 0.0023 \\
\hline Lung metastasis & $79(44 \%)$ & $40(39 \%)$ & $39(51 \%)$ & 0.1272 \\
\hline Pleural metastasis/pleural effusion & $76(42 \%)$ & $43(42 \%)$ & $33(43 \%)$ & 0.9252 \\
\hline Bone metastasis & $96(54 \%)$ & $56(55 \%)$ & $40(52 \%)$ & 0.6948 \\
\hline Liver metastasis & $21(12 \%)$ & $14(14 \%)$ & $7(9 \%)$ & 0.3401 \\
\hline Adrenal metastasis & $15(8 \%)$ & $7(7 \%)$ & $8(10 \%)$ & 0.3992 \\
\hline Other sites metastasis & $10(6 \%)$ & $4(4 \%)$ & $6(8 \%)$ & 0.2643 \\
\hline
\end{tabular}

eCCr-CG: estimated creatinine clearance rate using Cockcroft-Gault equation, and $\mathrm{CrCl}$ is multiplied by 0.85 for female patients.

** eGFR-MDRD: estimated glomerular filtration rate using Modification of Diet in Renal Disease equation. GFR is multiplied by 0.742 and 1.212 for female patients and African- American, respectively.

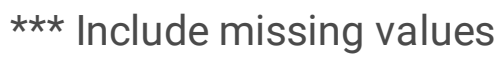

Table 2. Initial treatment response to different initial afatinib doses 


\begin{tabular}{|lllll|}
\hline Variables & $\begin{array}{l}\text { All } \\
\text { patients }\end{array}$ & $\begin{array}{l}\text { Afatinib 30 mg } \\
\text { QD }\end{array}$ & $\begin{array}{l}\text { Afatinib 40 mg } \\
\text { QD }\end{array}$ & $\begin{array}{c}\text { P } \\
\text { value }\end{array}$ \\
\hline Initial response to afatinib treatment $-n(\%)$ & & & 0.1661 \\
\hline Complete response & $2(1 \%)$ & $1(1 \%)$ & $1(1 \%)$ & \\
\hline Partial response & $\begin{array}{l}138 \\
(77 \%)\end{array}$ & $75(74 \%)$ & $63(82 \%)$ & \\
\hline Stable disease & $35(20 \%)$ & $25(25 \%)$ & $10(13 \%)$ & \\
\hline Progressive disease & $4(2 \%)$ & $1(1 \%)$ & $3(4 \%)$ & 0.1913 \\
\hline $\begin{array}{l}\text { Disease control rate with afatinib } \\
\text { treatment (\%) }\end{array}$ & $\begin{array}{l}175 \\
(98 \%)\end{array}$ & $101(99 \%)$ & $74(96 \%)$ & 0.1672 \\
\hline $\begin{array}{l}\text { Response rate with afatinib treatment } \\
(\%)\end{array}$ & $\begin{array}{l}140 \\
(78 \%)\end{array}$ & $76(75 \%)$ & $64(83 \%)$ & \\
\hline
\end{tabular}

Table 3. Cox regression analyses to identify the factors associated with progression-free survival.

\begin{tabular}{|c|c|c|c|c|}
\hline \multirow[t]{2}{*}{ Variables } & \multicolumn{2}{|c|}{ Univariate analysis } & \multicolumn{2}{|c|}{ Multivariable analysis } \\
\hline & $\mathrm{HR}[95 \% \mathrm{Cl}]$ & $\begin{array}{l}P \\
\text { value }\end{array}$ & $\mathrm{HR}[95 \% \mathrm{Cl}]$ & $\begin{array}{l}P \\
\text { value }\end{array}$ \\
\hline Afatinib dose (40mg daily vs. $30 \mathrm{mg}$ daily) & $\begin{array}{l}0.94[0.64- \\
1.36]\end{array}$ & 0.7319 & & \\
\hline Sex (male vs. female) & $\begin{array}{l}1.12[0.76- \\
1.64]\end{array}$ & 0.5652 & & \\
\hline Age $(\geq 65$ vs. $<65)$ & $\begin{array}{l}0.92[0.63- \\
1.33]\end{array}$ & 0.6440 & & \\
\hline $\begin{array}{l}\text { Smoking history (ever smokers vs. never } \\
\text { smokers) }\end{array}$ & $\begin{array}{l}1.16[0.74- \\
1.82]\end{array}$ & 0.5067 & & \\
\hline ECOG ( $\geq 2$ vs. $\leq 1)$ & $\begin{array}{l}1.18[0.73- \\
1.92]\end{array}$ & 0.5018 & & \\
\hline Exon 21 vs. exon 19 & $\begin{array}{l}1.17[0.81- \\
1.71]\end{array}$ & 0.4071 & & \\
\hline Stage (IV vs. others) & $\begin{array}{l}1.51[0.79- \\
2.90]\end{array}$ & 0.2155 & & \\
\hline $\begin{array}{l}\text { Number of metastatic sites ( } \geq 2 \text { sites vs. } \leq 1 \\
\text { site) }\end{array}$ & $\begin{array}{l}1.28[1.09- \\
1.51]\end{array}$ & 0.0026 & $\begin{array}{l}1.28[1.09- \\
1.50]\end{array}$ & 0.0030 \\
\hline Dose reduction (yes vs. no) & $\begin{array}{l}0.55[0.33- \\
0.91]\end{array}$ & 0.0209 & $\begin{array}{l}0.56[0.34- \\
0.92]\end{array}$ & 0.0229 \\
\hline
\end{tabular}


*Multivariable Cox regression models were built using backward variable selection method, keeping only variables with $p$ values less than 0.1

Table 4. Cox regression analyses to identify factors associated with overall survival.

\begin{tabular}{|c|c|c|c|c|}
\hline \multirow[t]{2}{*}{ Variables } & \multicolumn{2}{|c|}{ Univariate analysis } & \multicolumn{2}{|c|}{ Multivariable analysis } \\
\hline & $\mathrm{HR}[95 \% \mathrm{Cl}]$ & $\begin{array}{l}P \\
\text { value }\end{array}$ & $\mathrm{HR}[95 \% \mathrm{Cl}]$ & $\begin{array}{l}P \\
\text { value }\end{array}$ \\
\hline Afatinib dose (40mg daily vs. $30 \mathrm{mg}$ daily) & $\begin{array}{l}1.02[0.64- \\
1.63]^{-}\end{array}$ & 0.9239 & & \\
\hline Sex (male vs. female) & $\begin{array}{l}1.65[1.03- \\
2.63]^{-}\end{array}$ & 0.0354 & $\begin{array}{l}1.68[1.05- \\
2.69]\end{array}$ & 0.0307 \\
\hline Age $(\geq 65$ vs. $<65)$ & $\begin{array}{l}1.09[0.69- \\
1.74]\end{array}$ & 0.7078 & & \\
\hline $\begin{array}{l}\text { Smoking history (ever smokers vs. never } \\
\text { smokers) }\end{array}$ & $\begin{array}{l}1.49[0.88- \\
2.52]\end{array}$ & 0.1411 & & \\
\hline ECOG $(\geq 2$ vs. $\leq 1)$ & $\begin{array}{l}2.50[1.50- \\
4.19]\end{array}$ & 0.0005 & $\begin{array}{l}2.21[1.31- \\
3.74]\end{array}$ & 0.0029 \\
\hline Exon 21 vs. exon 19 & $\begin{array}{l}0.97[0.61- \\
1.54]\end{array}$ & 0.8912 & & \\
\hline Stage (IV vs. others) & $\begin{array}{l}2.46[0.90- \\
6.75]\end{array}$ & 0.0805 & & \\
\hline $\begin{array}{l}\text { Number of metastatic sites ( } \geq 2 \text { sites vs. } \leq 1 \\
\text { site) }\end{array}$ & $\begin{array}{l}1.37[1.12- \\
1.68]^{-}\end{array}$ & 0.0019 & $\begin{array}{l}1.34[1.09- \\
1.65]\end{array}$ & 0.0056 \\
\hline Dose reduction (yes vs. no) & $\begin{array}{l}0.96[0.55- \\
1.69]\end{array}$ & 0.8995 & & \\
\hline
\end{tabular}

*Multivariable Cox regression models were built using the backward variable selection method, keeping only variables with $\mathrm{p}$ values $<0.1$

Table 5. Adverse drug reactions related to different initial afatinib dosages 


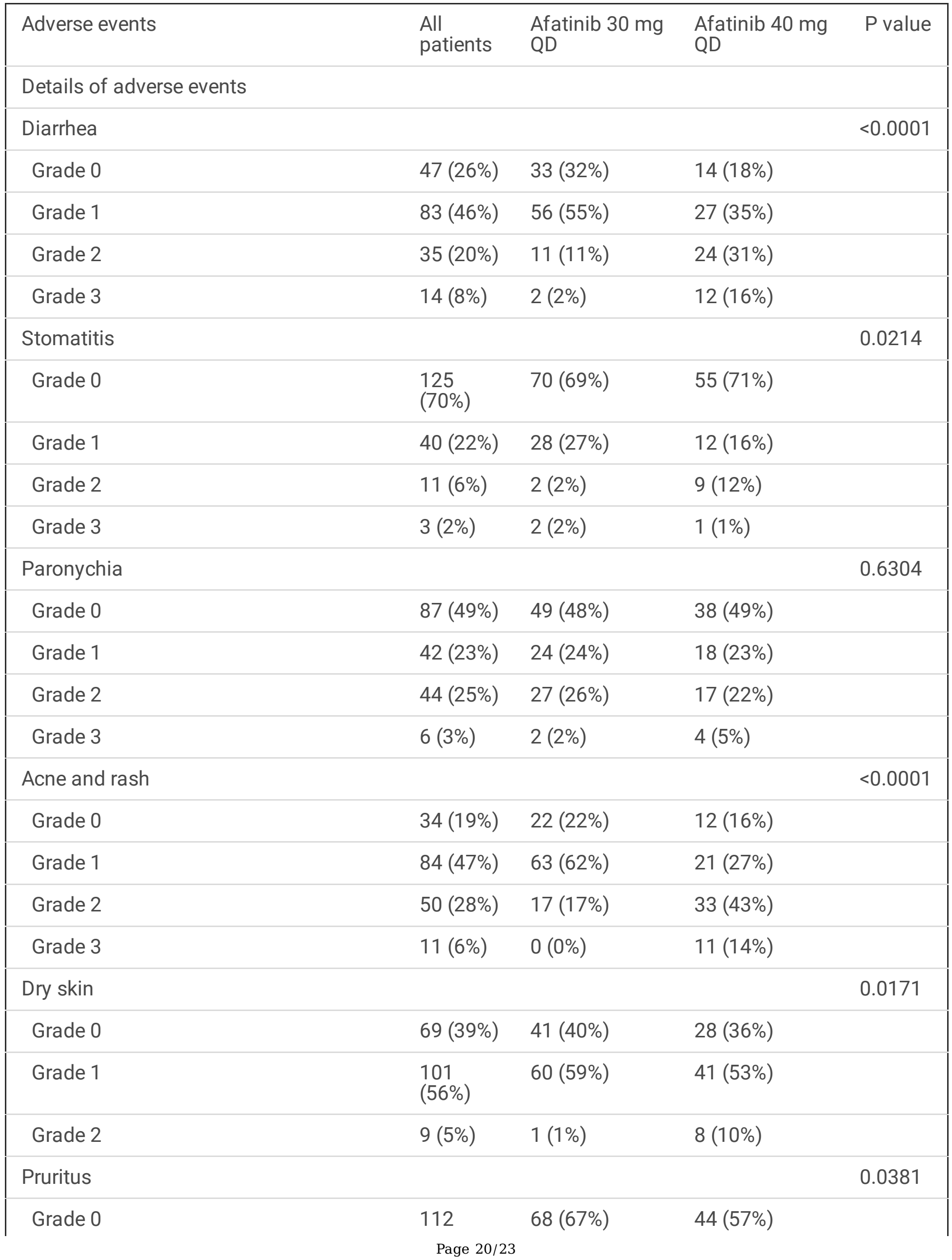


$(63 \%)$

$\begin{array}{llll}\text { Grade } 1 & 58(32 \%) & 33(32 \%) & 25(32 \%) \\ \text { Grade } 2 & 8(4 \%) & 1(1 \%) & 7(9 \%) \\ \text { Grade 3 } & 1(1 \%) & 0(0 \%) & 1(1 \%)\end{array}$

All about skin adverse events

\begin{tabular}{|c|c|c|c|c|}
\hline Grade 0 & $24(13 \%)$ & 16 (16\%) & $8(10 \%)$ & \\
\hline Grade 1 & 93 (52\%) & 68 (67\%) & 25 (32\%) & \\
\hline Grade 2 & $51(28 \%)$ & $18(18 \%)$ & 33 (43\%) & \\
\hline Grade 3 & $11(6 \%)$ & $0(0 \%)$ & $11(14 \%)$ & \\
\hline Hepatitis & & & & 0.1382 \\
\hline Grade 0 & $\begin{array}{l}172 \\
(96 \%)\end{array}$ & 100 (98\%) & 72 (94\%) & \\
\hline Grade 1 & $3(2 \%)$ & $1(1 \%)$ & 2 (3\%) & \\
\hline Grade 2 & $3(2 \%)$ & $0(0 \%)$ & $3(4 \%)$ & \\
\hline Grade 3 & $1(1 \%)$ & $1(1 \%)$ & $0(0 \%)$ & \\
\hline $\mathrm{ILD}^{*}$ & $2(1 \%)$ & $2(2 \%)$ & $0(0 \%)$ & 0.2166 \\
\hline
\end{tabular}

Patients suffer from grades of max adverse events

$<0.0001$

$\begin{array}{llll}\text { Grade } 0 & 8(4 \%) & 2(2 \%) & 6(8 \%) \\ \text { Grade } 1 & 62(35 \%) & 50(49 \%) & 12(16 \%) \\ \text { Grade 2 } & 78(44 \%) & 43(42 \%) & 35(45 \%) \\ \text { Grade 3 } & 31(17 \%) & 7(7 \%) & 24(31 \%)\end{array}$

Presence of adverse events

\begin{tabular}{|c|c|c|c|c|}
\hline Diarrhea & $\begin{array}{l}132 \\
(74 \%)\end{array}$ & $69(68 \%)$ & $63(82 \%)$ & 0.0329 \\
\hline Moderate to severe ( $\geqq$ Grade 2 ) & $49(27 \%)$ & $13(13 \%)$ & $36(47 \%)$ & $<0.0001$ \\
\hline Severe $(\geqq$ Grade 3$)$ & $14(8 \%)$ & $2(2 \%)$ & $12(16 \%)$ & 0.0008 \\
\hline Stomatitis & $54(30 \%)$ & $32(31 \%)$ & $22(29 \%)$ & 0.686 \\
\hline Moderate to severe ( $\geqq$ Grade 2 ) & $14(8 \%)$ & $4(4 \%)$ & $10(13 \%)$ & 0.0253 \\
\hline Severe $(\geqq$ Grade 3 ) & $3(2 \%)$ & $2(2 \%)$ & $1(1 \%)$ & 0.7326 \\
\hline Paronychia & 92 (51\%) & 53 (52\%) & 39 (51\%) & 0.862 \\
\hline
\end{tabular}




\begin{tabular}{|c|c|c|c|c|}
\hline Moderate to severe ( $\geqq$ Grade 2 ) & $50(28 \%)$ & $29(28 \%)$ & $21(27 \%)$ & 0.8642 \\
\hline Severe ( $\geqq$ Grade 3 ) & $6(3 \%)$ & $2(2 \%)$ & $4(5 \%)$ & 0.234 \\
\hline Acne and rash & $\begin{array}{l}145 \\
(81 \%)\end{array}$ & $80(78 \%)$ & $65(84 \%)$ & 0.3122 \\
\hline Moderate to severe ( $\geqq$ Grade 2 ) & $61(34 \%)$ & $17(17 \%)$ & $44(57 \%)$ & $<0.0001$ \\
\hline Severe $(\geqq$ Grade 3 ) & $11(6 \%)$ & $0(0 \%)$ & $11(14 \%)$ & $<0.0001$ \\
\hline Dry skin ${ }^{\star *}$ & $\begin{array}{l}110 \\
(61 \%)\end{array}$ & $61(60 \%)$ & $49(64 \%)$ & 0.602 \\
\hline Moderate to severe ( $\geqq$ Grade 2 ) & $9(5 \%)$ & $1(1 \%)$ & $8(10 \%)$ & 0.0043 \\
\hline Pruritus & $67(37 \%)$ & $34(33 \%)$ & $33(43 \%)$ & 0.1924 \\
\hline Moderate to severe ( $\geqq$ Grade 2 ) & $9(5 \%)$ & $1(1 \%)$ & $8(10 \%)$ & 0.0043 \\
\hline Severe $(\geqq$ Grade 3 ) & $1(1 \%)$ & $0(0 \%)$ & $1(1 \%)$ & 0.2484 \\
\hline All about skin adverse events & $\begin{array}{l}155 \\
(87 \%)\end{array}$ & $86(84 \%)$ & $69(90 \%)$ & 0.3032 \\
\hline Moderate to severe ( $\geqq$ Grade 2 ) & $62(35 \%)$ & $18(18 \%)$ & $44(57 \%)$ & $<0.0001$ \\
\hline Severe $(\geqq$ Grade 3$)$ & $11(6 \%)$ & $0(0 \%)$ & $11(14 \%)$ & $<0.0001$ \\
\hline Hepatitis & $7(4 \%)$ & $2(2 \%)$ & $5(6 \%)$ & 0.1214 \\
\hline Moderate to severe ( $\geqq$ Grade 2 ) & $4(2 \%)$ & $1(1 \%)$ & $3(4 \%)$ & 0.1913 \\
\hline Severe $(\geqq$ Grade 3 ) & $1(1 \%)$ & $1(1 \%)$ & $0(0 \%)$ & 0.3836 \\
\hline ILD* & $2(1 \%)$ & $2(2 \%)$ & $0(0 \%)$ & 0.2166 \\
\hline $\begin{array}{l}\text { Patients suffer from grades of max } \\
\text { adverse events }\end{array}$ & $\begin{array}{l}171 \\
(96 \%)\end{array}$ & $100(98 \%)$ & $71(92 \%)$ & 0.0616 \\
\hline Moderate to severe ( $\geqq$ Grade 2 ) & $\begin{array}{l}109 \\
(61 \%)\end{array}$ & $50(49 \%)$ & $59(77 \%)$ & 0.0002 \\
\hline Severe ( $\geqq$ Grade 3 ) & $31(17 \%)$ & $7(7 \%)$ & $24(31 \%)$ & $<0.0001$ \\
\hline
\end{tabular}

* ILD: Interstitial lung disease; ** There were no severe ( $\geqq$ grade 3 ) adverse events of dry skin.

\section{Figures}


Fig $1 \mathrm{~A}$

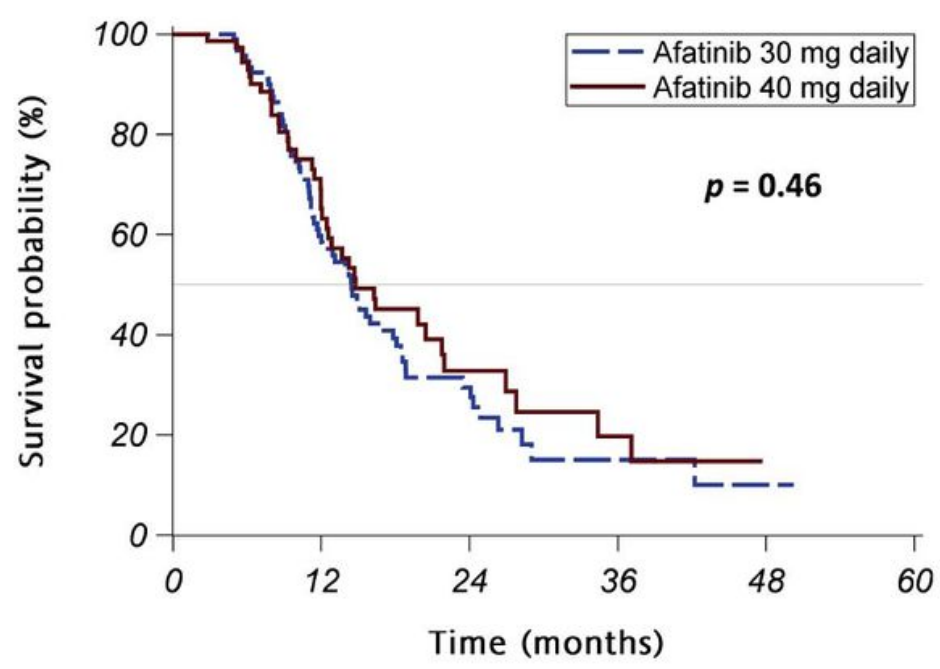

Fig 1B

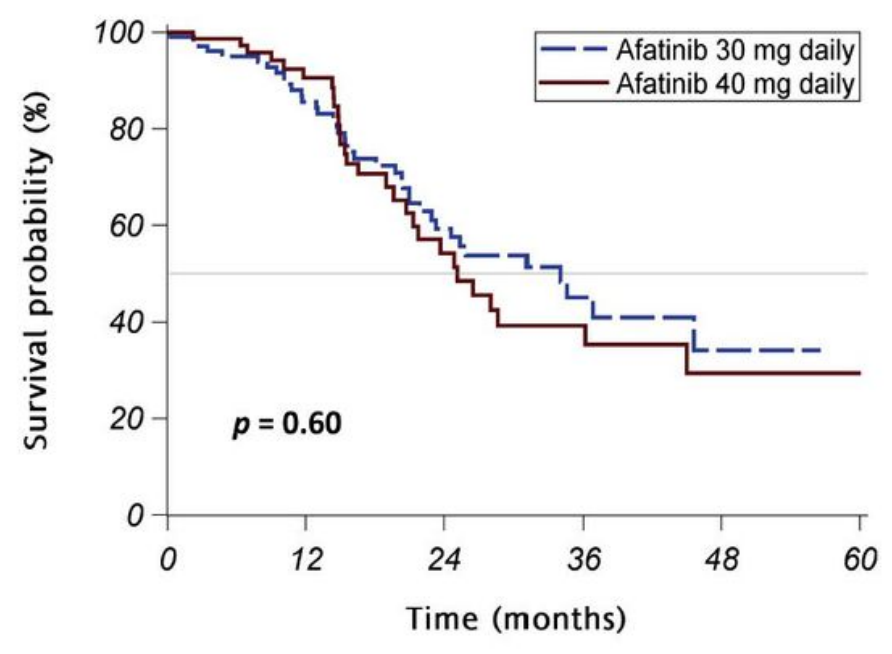

Figure 1

PFS and OS for afatinib treatment. (A) PFS in patients receiving different initial doses of afatinib. (B) OS for patients receiving different initial doses of afatinib.

\section{Supplementary Files}

This is a list of supplementary files associated with this preprint. Click to download.

- JEN200801RTable7.docx

- JEN200801RTable6.docx 